\title{
Nutritional Sustainability for a Child towards Isolation of Aspergillus Species from Some Cereals and Legumes Sold in Enugu
}

\section{Dozie-Nwakile $\mathrm{OC}^{1 *}$, Onyemelukwe $\mathrm{NF}^{1}$, Nwakile $\mathrm{CD}^{2}$, Okenwa $\mathrm{CE}^{1}$, Okongwu $\mathrm{U}^{\mathbf{1}}$, Ukpai $\mathrm{NU}^{\mathbf{1}}$ and Ilo $\mathrm{AC}^{\mathbf{1}}$}

${ }^{1}$ Department of Medical Laboratory Sciences, Faculty of Health Sciences and Technology College of Medicine, University of Nigeria, Enugu Campus, Enugu State, Nigeria

${ }^{2}$ Department of Pharmaceutics and Pharmaceutical Technology, Faculty of Pharmaceutical Sciences Nnamdi Azikiwe University Agulu Campus, Awka, Anambra State, Nigeria

*Corresponding Author: Dozie-Nwakile OC, Department of Medical Laboratory Sciences, Faculty of Health Sciences and Technology College of Medicine, University of Nigeria, Enugu Campus, Enugu State, Nigeria.
Received: March 30, 2020

Published: May 02, 2020

(C) All rights are reserved by Gisele Ferreira De Souza and Jair Ribeiro Dos Santos Junior.

\begin{abstract}
Background of the Study: Most of Nigerian staple foods especially cereals (rice and beans) are liable to aflatoxin contamination due to inherent high temperature and humidity favouring the growth of aflatoxin-producing Aspergillus spp.

Objective: This study was therefore conducted to determine the rate of contamination of some rice and beans varieties sold in Enugu state.

Methodology: A total of 220 samples were randomly purchased from various markets in Enugu state and analysed using standard mycological techniques.

Results: Of the total of 243 fungal isolates the most predominant were Aspergillus spp 106 (43.6\%) with more numbers in rice varieties $84(50.3 \%)$ than beans varieties $22(28.9 \%)$. This is followed by Rhizopus spp $88(36.2 \%)$.

Statistical Analysis: All generated data were subjected to statistical analysis using SPSS version 24. Confidence interval was recorded at $\mathrm{P}<0.05$ limit.molars.

Conclusion: This study showed that rice and beans sold in Enugu were contaminated by fungal agents irrespective of the variety and some of these fungal agents and their metabolites (aflatoxins) pose a serious health hazard either through consumption or inhalation. Keywords: Rice; Cowpeas; Aflatoxins
\end{abstract}

\section{Introduction}

Cowpea (Vigna ungulculata (L) Walp) like other legumes is an important foodstuff in tropical and subtropical countries. It is widely grown cultivated and distributed in Africa, Asia, West Indies, Latin America and India. The legume can be grown in marginal soils and in arid or semi-arid regions. Its deep penetrating root systems enable it to withstand very dry conditions. The nutritional value of about $25 \%$ protein is highly valuable where many people cannot afford animal protein [1] especially in children. The protein have well recognized deficiency of the essential sulphur-bearing amino-acids, methionine and cystine [2].

Rice (Oryzae sativa Linn.) is a wholesome cereal grain that is ideal for diverse nutritional needs. It contains predominantly carbohydrates besides vitamins and fibre and has higher proportion of protein than in wheat, corn and sorghum [3]. It has become the predominant staple food in about 33 countries of the world including Nigeria [4]. About 90 - 95\% of Nigerians consume rice and this cut across all economic class where it is eaten in different recipes [5]. Despite Nigerian being the highest producer of rice in West Africa the yield in Nigerian is low compared to other parts of the world. This limited rice and cowpea produced is further reduced during post-harvest storage [6] due to the prevailing high temperature and relative humidity which encourage colonization of moulds. Moulds have been found to contaminate maize [7], wheat [8] and rice [9-11]. The presence of moulds in stored grains may lead to various forms of deterioration, visible mouldiness, seed discolouration [12] and decreased nutritive value [13]. However, the most debilitating effect of mould deterioration of stored grain and seeds is mycotoxin production [14]. Mycotoxins are important in 
food safety in that they not only lead to deleterious health effects in humans and animals but also pose adverse economic implications especially the aflatoxins caused by some species of Aspergillus $[15,16]$.

Aflatoxin is about the most popular and widespread mycotoxin [16]. They are secondary metabolites produced by the species of Aspergillus that contaminate a variety of agricultural food commodities [15]. They are recognized to be hepatotoxins and carcinogens for humans [17]. Aspergillus and Penicillins produce their toxins mostly in stored seeds, hay or commercially processed foods and feeds although infection of seeds usually takes place in the field [18]. Several disease outbreaks of aflatoxicosis in humans and animals have been reported due to the consumption of aflatoxin contaminated food and feed [19].

In Nigeria rice and cowpea (beans) are used for a variety of food and nonfood products (snacks) and they are some of the important cereals which favour aflatoxin production [20]. Both the toxigenic fungi and the secondary metabolites they produce are potential problems in both health and economic perspectives. Also fumes from burning molded hay may also affect animals and man handling of such hay thereby causing in them dermatitis and conjuctivities.

\section{Objective of the Study}

The objective of this study is to isolate some species of Aspergillus and other fungi associated with rice and beans as part of information towards formulating control regimens against the dreaded mycotoxins in this part of the world.

\section{Methodology}

Sample collection

A total of 220 samples were randomly selected from rice and beans varieties from different markets in Enugu state. These samples include exposed and unexposed samples. The research work was carried out between June and July 2019 in Enugu.

\section{Culture of samples}

Samples of different varieties of rice and beans were surface sterilized using $0.1 \%$ sodium hypochlorite and then rinsed in two changes of sterile water. They were separately inoculated on a Sabouraud Dextrose agar slants supplemented with $50 \mathrm{mcg} / \mathrm{l}$ of chloramphenicol and incubated for two weeks. All tubes showing significant growth were examined and identified according to Frazier WC and Westhoff DC [21].

\section{Statistical analysis}

This was done using Turkey's multiple tests and the student's $\mathrm{t}$ - Test SPSS version 24. There was statistically significant difference between the Aspergillus spp isolates in rice and beans varieties $(\mathrm{P}<0.05)$. No statistically significant differences were observed among the exposed beans varieties and rice varieties $(\mathrm{P}>0.05)$ in the rate of other fungal isolates whereas a statistically significant variation was observed for the unexposed samples of rice varieties and beans varieties studied respectively $(\mathrm{P}<0.05)$.

\section{Results}

\begin{tabular}{|l|c|c|}
\hline \multicolumn{1}{|c|}{ Fungal Isolates } & Rice & Cowpea \\
\hline Rhizopus spp & $48(28.7 \%)$ & $40(52.6 \%)$ \\
\hline Aspergillus niger & $44(26.3 \%)$ & $12(15.8 \%)$ \\
\hline Aspergillus flavus & $18(10.8 \%)$ & $8(10.5 \%)$ \\
\hline T. mentagrophytes & $15(9.0 \%)$ & $3(3.9 \%)$ \\
\hline Aspergillus fumigatus & $13(7.8 \%)$ & $2(2.6 \%)$ \\
\hline Mucor spp & $9(5.4 \%)$ & - \\
\hline Geotrichum spp & $8(4.8 \%)$ & - \\
\hline Aspergillus. tamarri & $3(1.8 \%)$ & - \\
\hline Synephalastrum spp & $2(1.2 \%)$ & $8(10.5 \%)$ \\
\hline Aspergillus clavatus & $2(1.2 \%)$ & - \\
\hline Aspergillus restrictus & $2(1.2 \%)$ & - \\
\hline T. rubrum & $1(0.6 \%)$ & - \\
\hline Aspergillus caesiellus & $1(0.6 \%)$ & - \\
\hline Microsporum canis & - & $2(2.6 \%)$ \\
\hline Scopulariopsis spp & - & $1(1.3 \%)$ \\
\hline Aspergillus oryzae & $1(0.6 \%)$ & - \\
\hline Total & $167(68.7 \%)$ & $76(31.3 \%)$ \\
\hline
\end{tabular}

Table 1: Total number of fungal isolates from rice and cowpea.

\begin{tabular}{|l|c|c|c|c|c|}
\hline \multicolumn{1}{|c|}{$\begin{array}{c}\text { Fungal } \\
\text { isolates }\end{array}$} & $\begin{array}{c}\text { White } \\
\text { Exposed }\end{array}$ & $\begin{array}{c}\text { Brown } \\
\text { Exposed }\end{array}$ & $\begin{array}{c}\text { White Un- } \\
\text { exposed }\end{array}$ & $\begin{array}{c}\text { Brown } \\
\text { Unex- } \\
\text { posed }\end{array}$ & Total \\
\hline Rhizopus spp & $12(75 \%)$ & $9(45 \%)$ & $10(55.6 \%)$ & $\begin{array}{c}9 \\
(40.9 \%)\end{array}$ & $\begin{array}{c}40 \\
(52.6 \%)\end{array}$ \\
\hline $\begin{array}{l}\text { Aspergillus } \\
\text { niger }\end{array}$ & $1(6.25 \%)$ & $3(15 \%)$ & $1(5.6 \%)$ & $\begin{array}{c}7 \\
(31,8 \%)\end{array}$ & $\begin{array}{c}12 \\
(15.8 \%)\end{array}$ \\
\hline $\begin{array}{l}\text { Aspergillus } \\
\text { flavus }\end{array}$ & $1(6.25 \%)$ & $4(20 \%)$ & $2(11.1 \%)$ & $1(4.5 \%)$ & $\begin{array}{c}8 \\
(10.5 \%)\end{array}$ \\
\hline $\begin{array}{l}\text { Syncephalas- } \\
\text { trum spp }\end{array}$ & - & - & $2(11.1 \%)$ & $2(9.1 \%)$ & $\begin{array}{c}8 \\
(10.5 \%)\end{array}$ \\
\hline $\begin{array}{l}\text { T. mentagro- } \\
\text { phytes }\end{array}$ & $1(6.25 \%)$ & - & $2(11.1 \%)$ & - & $3(3.9 \%)$ \\
\hline M. canis & - & - & - & $2(9.1 \%)$ & $2(2.6 \%)$ \\
\hline $\begin{array}{l}\text { Aspergillus } \\
\text { fumigatus }\end{array}$ & - & - & $1(5.6 \%)$ & $1(4.5 \%)$ & $2(2.6 \%)$ \\
\hline $\begin{array}{l}\text { Scopulariop- } \\
\text { sis spp }\end{array}$ & $1(6.25 \%)$ & - & - & - & $1(1.3 \%)$ \\
\hline $\begin{array}{l}\text { Total } \\
(21.1 \%)\end{array}$ & $(26.3 \%)$ & $18(23.7 \%)$ & $\begin{array}{c}22 \\
(28.9 \%)\end{array}$ & $\begin{array}{c}76 \\
(100 \%)\end{array}$ \\
\hline
\end{tabular}

Table 2: Distribution of fungal isolates according to different varieties of exposed and unexposed cowpeas. 


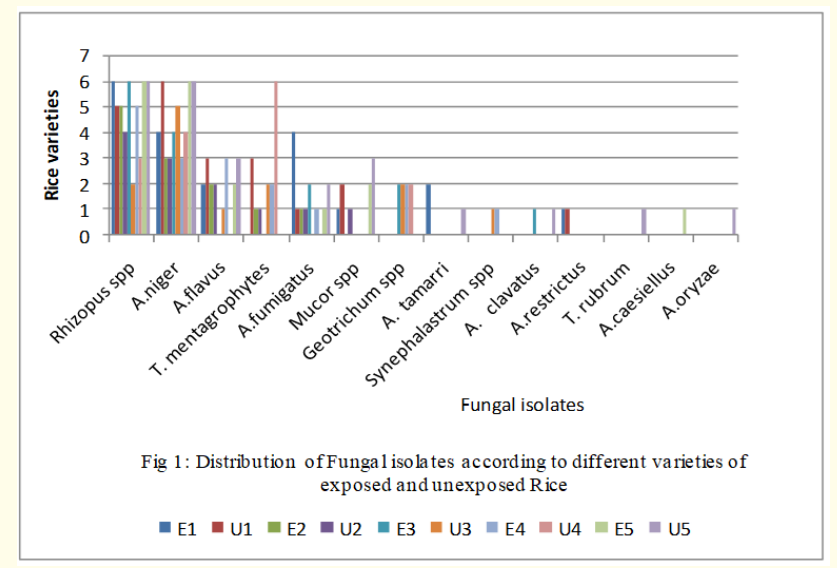

Figure 2: Distribution of fungal isolates according to different varieties of exposed and unexposed rice.

Key: E1 U1= Abakaliki; E2 U2= Adani; E3 U3 = Oduma; E4 U4= Ugbawka and E5 U5 = Foreign.

\section{Discussion}

Rhizopus species were the highest fungi isolated in the varieties of cowpeas and rice studied. A total of 40 (52.6\%); 48 (28.7\%) Rhizopus species out of 76 (31.3\%) cowpeas and 167 (68.7\%) rice fungal isolates encountered respectively. There was a statistical significance difference between the two cereals worked upon $(\mathrm{P}<$ 0.05). The reason could be due to the fact that Rhizopus species are thermotolerant saprobes and so the heat generated upon storage favour their growth [22]. The second predominant fungi encountered were Aspergillus niger and Aspergillus flavus 12 (15.8\%); 8 (10.5\%) and 44 (26.3\%); 18 (10.8\%) in both cowpeas and rice respectively. This could be attributed to their wide distribution in nature, being saprophytes in the soil, decaying vegetation and other substances according to Madunagu and Umana [23]; Onyeka and Ugwu [24]. This also agrees with the work of Somorin and Bankole [25], who reported that Aspergillus species were the most predominant fungi in "Ofada" and "Abakaliki" rice in Lagos

\begin{tabular}{|l|c|c|c|c|c|}
\hline \multicolumn{1}{|c|}{ Aspergillus spp } & No of isolates & White Exposed & White Unexposed & Brown Exposed & Brown Unexposed \\
\hline Aspergillus fumigatus & $2(9.09 \%)$ & 0 & 1 & 0 & 1 \\
\hline Aspergillus niger & $12(54.5 \%)$ & 1 & 1 & 3 & 7 \\
\hline Aspergillus flavus & $8(36.4 \%)$ & 1 & 2 & 4 & 1 \\
\hline Total & 22 & $2(9.1 \%)$ & $4(18.2 \%)$ & $7(31.8 \%)$ & $9(40.1 \%)$ \\
\hline
\end{tabular}

Table 3: Distribution of Aspergillus species according to different varieties of cowpeas.

\begin{tabular}{|l|c|c|c|c|}
\hline \multicolumn{1}{|c|}{ Aspergillus spp } & No of isolates & Exposed & Unexposed & Frequency (\%) \\
\hline Aspergillus niger & 44 & 20 & 24 & 52.4 \\
\hline Aspergillus flavus & 18 & 9 & 4 & 21.4 \\
\hline Aspergillus fumigatus & 13 & 2 & 1 & 15.5 \\
\hline Aspergillus tamarri & 3 & 1 & 1 & 3.6 \\
\hline Aspergillus clavatus & 2 & 1 & 1 & 2.4 \\
\hline Aspergillus restrictus & 2 & 1 & 1 & 2.4 \\
\hline Aspergillus caesiellus & 1 & 1 & 0 & 1.2 \\
\hline Aspergillus oryzae & 1 & 0 & 1 & 1.2 \\
\hline Total & 84 & 43 & 41 & 100 \\
\hline
\end{tabular}

Table 4: Distribution of Aspergillus species according to different varieties of rice.

\begin{tabular}{|l|c|c|c|c|c|c|}
\hline \multicolumn{1}{|c|}{ Fungal genera } & Abakaliki & Adani & Oduma & Ugbawka & Foreign & Total \\
\hline Aspergillus spp & $24(28.6 \%)$ & $12(14.3 \%)$ & $13(15.5 \%)$ & $11(13.1 \%)$ & $24(28.6 \%)$ & $84(50.3 \%)$ \\
\hline Rhizopus spp & $11(23 \%)$ & $9(18.8 \%)$ & $8(16.7 \%)$ & $8(16.7 \%)$ & $12(25 \%)$ & $48(28.7 \%)$ \\
\hline Trichophyton spp & $3(18.8 \%)$ & $2(12.5 \%)$ & $2(12.5 \%)$ & $8(50 \%)$ & $1(6.3 \%)$ & $16(9.6 \%)$ \\
\hline Mucor spp & $3(33.3 \%)$ & $1(11.1 \%)$ & - & - & $5(55.6 \%)$ & $9(5.4 \%)$ \\
\hline Geotrichum spp & - & - & $4(50 \%)$ & $4(50 \%)$ & - & $8(4.8 \%)$ \\
\hline Syncephalastrum spp & - & - & $1(50 \%)$ & $1(50 \%)$ & - & $2(1.2 \%)$ \\
\hline Total & $41(24.6 \%)$ & $24(14.4 \%)$ & $28(16.8 \%)$ & $32(19.2 \%)$ & $42(25.1 \%)$ & 167 \\
\hline
\end{tabular}

Table 5: Distribution of fungal isolates according to genera in different varieties of rice. 


\begin{tabular}{|l|c|c|c|}
\hline \multicolumn{1}{|c|}{ Fungal genera } & White & Brown & Total \\
\hline Rhizopus spp & $44(31.4 \%)$ & $96(68.6 \%)$ & $140(66 \%)$ \\
\hline Aspergillus spp & $12(27.3 \%)$ & $32(72.7 \%)$ & $44(20.8 \%)$ \\
\hline Trichophyton spp & $6(33.3 \%)$ & $12(66.7 \%)$ & $18(8.5 \%)$ \\
\hline Syncephalastrum spp & $4(50 \%)$ & $4(50 \%)$ & $8(3.8 \%)$ \\
\hline Scopulariopsis spp & $2(100 \%)$ & - & $2(0.9 \%)$ \\
\hline Total & $68(32.1 \%)$ & $144(67.9 \%)$ & 212 \\
\hline
\end{tabular}

Table 6: Distribution of fungal isolates according to Genera in different varieties of cowpeas.

and Ogun states of Nigeria. Hence there was a statistical significant difference between the Aspergillus species isolated from cowpeas and rice varieties in this work $(\mathrm{P}<0.05)$. These results were shown in table 1. Among the cowpeas varieties it was observed that unexposed brown cowpeas had the highest number of fungal isolates 22 (28.9\%) with Rhizopus spp ranking highest 9 (40.9\%). Mycelia sterilia were seen among the Scopulariopsis spp in the brown cowpea exposed and unexposed. Also, the same were recorded among the Syncephalastrum spp of white and brown cowpeas exposed varieties. Some dermatophytes like Microsporon and Trichophyton spp recorded maybe as a result of presence of superficial mycoses from unhygienic practices accompanying the retailers according to Gallardo., et al. [26] and Kayser., et al [27]. Most probable reason could be due geophilic nature of these dermatophytes. These results were shown in table 2 . There was no statistically significant difference between the fungal isolates of the exposed white and brown cowpeas and the unexposed white and brown cowpeas in this work $(\mathrm{P}>0.05)$. In table 3 , there was a tremendous increase in the total number of fungal isolates in the unexposed foreign rice variety followed by Abakaliki rice. These were represented graphically in figure 1 . This agreed with the work of Somorin and Bankole [25] as earlier mentioned. Among the genera isolates Aspergillus species ranked highest 84 (50.3\%) followed by Rhizopus species $48(28.7 \%)$ out of 167 genera fungal isolates in rice varieties while Rhizopus species 140 (66\%) ranked highest followed by Aspergillus species $44(20.8 \%)$ in the cowpeas varieties. The reason could be that, according to retailers due to the chemicals they normally spray on these cereals during storage do not stick on the rice and swifts off easily on the cowpeas soft seed coat after some time attracting weevils and some rodents which deposit their excretas on them. Under high humidity and temperature favour the growth of moulds. This agrees with the work of Dawar., et al. [28] who found out that Aspergillus species are saprophytic and will continue to grow on pulses as long as conditions of high temperature and relative humidity support it. Hence, there was a statistically significant difference between the number of Aspergillus species in rice and cowpeas $(\mathrm{P}<0.05)$. These are shown in table 5 and 6 respectively.

\section{Conclusion}

This study has demonstrated that cowpeas both exposed and unexposed habour fungal agents and have the ability to transfer these pathogens to humans, causing fungal infections such as aspergilloma. This study demonstrates that the so called "foreign" rice has no advantage, in terms of safety, over the local rice. Rice grains exposed and unexposed of both local and "foreign" accommodate the growth of fungal agents and have the ability to cause diseases in humans animals alike.

\section{Bibliography}

1. Akpapunam MA and Sefa- Dedeh S. "Jack Bean Canavalia Ensiformis Nutrition Relation. Aspects and needed Nutrition Research". Journal of Plant Food for Human Nutrition 10 (1997): 123-127.

2. Ihekoronye AI and Ngoddy PO. "Integrated Food Science and Technology for the Tropics. Macmillian Publishers, London (1985): 180-191.

3. USA Rice Federation (2002).

4. FAO. "Worldwide Regulations for Mycotoxins in Food and Feed in 2003". Food and Nutrition Paper 81. Rome (2004).

5. Wudiri BB. "Developing Appropriate Rice Processing Technologies for Nigeria". The NCRI Experience. In: Rice Processing in Nigeria. Proceedings of the MFA Workshop in Niger State by Babaleye T and Nwachukwu, I. Editors. IITA, Ibadan (1992): $24-31$

6. WARDA. "West African Rice Development Agency". African Rice Trends (2002).

7. Oral RB., et al. "Mycoflora and Occorrence of Fumonisins in freshly Harvested and Stored Hybrid Maize". Journal of Stored Products and Resources 36.1 (2000): 75-87.

8. Berghofer LK., et al. "Microbiology of Wheat and Flour Milling in Australia". International Journal for Food Microbiology 85.12 (2003): 137-149.

9. Desjardina AE., et al. "Fusarium Species from Nepalese Rice and Production of Mycotoxins and Gibberellic acid by selected species". Applied Environmental Microbiology 66.3 (2000): 1020-1025.

10. Park JW., et al. "Fungal Mycoflora and Mycotoxins in Korean Polished Rice Destined for Humans". International Journal of Food Microbiology 103 (2005): 305-314.

11. Sales A and Yoshizawa T. "Updated Profile of Aflatoxin and Aspergillus flavi Contamination in Rice and its By-Products from the Philippines". Food Additives and Contamination 22 (2005): 429-436.

12. Aboaba 00 and Amasike J. "Storage of Melon Seeds". Nigerian Journal of Botany 4 (1991): 213-219.

13. Maxiya-Dixon B. "Effects of Mycotoxins on Nutritional Quality of Food Crops". International Institute of Tropical Agriculture, Ibadan, Nigeria (2004). 
14. Bankole S and Adebanjo A. "Mycotoxin in food in West Africa. In: Current Situation and Possibilities of Controlling it". African Journal of Biotechnology 12.9 (2003): 254-263.

15. Bhat RV and Vashanti S. "Mycotoxin Food Safety Risk in Developing Countries”. In: Unneyehr LJ, editor. International Food Policy Research Institute. Focus 10 Vision 2020 Food Safety in Food Security and Food Trade (2003).

16. Wu F. "A Tale of two Commodities. In: How EU Mycotoxin Regulations have affected U.S Tree nut Industries". World Mycotoxin Journal 1.1 (2008): 95-102.

17. WHO. "Safety Evaluation of Certain Food Additives and Contaminants". Series 40 Rome (1998).

18. Amadi JE and Adeniyi DO. "Mycotoxin Production by Fungi Isolated from Stored Grains". African Journal of Biotechnology 8.7 (2009): 1219-1221.

19. Redd BN and Raghavender CR. "Outbreaks of aflatoxicoses in India”. African Journal of Food Agriculture Nutrition and Development 7 (2007): 1-15.

20. Makun HA., et al. "Fungi and Some Mycotoxins Contaminating Rice (Oryzae sativae) in Niger State, Nigeria”. African Journal of Biotechnology 6.2 (2007): 99-100.

21. Frazier WC and Westhoff DC. "Classification and Identification of molds/yeasts and yeast-like fungi”. In Food Microbiology, 4th Edition. McGraw-Hill Book Company, Singapore 17-39. (2002).

22. Richard J. "Some Major Mycotoxins, their Mycotoxicoses and overview". Journal of Food Microbiology 119 (2007): 3-10.

23. Madunagu B and Umana E. "Characteristics of Fungi”. In: Fundamentals of Mycology. Clear Lines Publications, Calabar, Nigeria (2000).

24. Onyeka CA and Ugwu IO. "Fungal Flora of Human Toe- web". Journal of Mycoses 45 (2000): 488-491.

25. Somorin YM and Bankole SA. "Mycoflora of Stored "Ofada" and "Abakaliki" Rice in Lagos and Ogun States, Southwestern Nigeria". African Journal of Microbiology Research 4.16 (2010): 1724-1726.

26. Gallardo S., et al. "Epidemiology of Dermatophytoses Observed in Rome, Italy between 1985 and 1993". Journal of Mycoses 38 (2004): 415-417.

27. Kayser FH., et al. "Medical Microbiology". Mycology (2004): 372-374.

28. Dawar S., et al. "Seed borne Fungi Associated with Chickpea in Pakistan". Pakistan Journal of Botany 39.2 (2007): 637-643.

\section{Assets from publication with us}

- Prompt Acknowledgement after receiving the article

- Thorough Double blinded peer review

- Rapid Publication

- Issue of Publication Certificate

- High visibility of your Published work

Website: https://www.actascientific.com/

Submit Article: https://www.actascientific.com/submission.php Email us: editor@actascientific.com

Contact us: +919182824667 